\title{
BOARD OF DIRECTORS QUALIFICATION AND COMPOSITION: STUDY OF ITS IMPACT ON SERVICE SECTOR OF INDIA
}

\author{
Rahul Singhal \\ Assistant Professor, Ajay Kumar Garg Institute of Management Ghaziabad, UP (India) \\ Email: rahul.singhal@akgim.edu.in \\ Vikhyat Singhal \\ Assistant Professor, IIMT Engineering College, Meerut, UP (India) \\ Email:Vikhyat3179@gmail.com \\ Ritesh Kumar Singhal \\ Associate Professor, Ajay Kumar Garg Institute of Management Ghaziabad, UP (India) \\ Email: ritesh@akgim.edu.in \\ Ajay Singh \\ Professor, IILM Graduate School of Management, Greater Noida, UP (India) \\ Email: ajayks10@gmail.com
}

\begin{abstract}
The purpose of this study was to determine the effects of education and composition of Board of Directors on the performance of firms listed at the Bombay Stock Exchange (BSE). The target population of this explanatory research study comprises of top performers of service sector firms listed at the Bombay Stock Exchange. The secondary data from the financial statements and annual reports of the listed companies covering the year 2015 19 was considered for the study. The correlation matrix and linear regression analysis technique was used to determine the effect of independent variables i.e. size of board, proportion of board with post-graduation qualification and proportion of independent directors in the board on the dependent variable i.e. return on equity and return on capital employed. The study findings indicate size of BODs and independence of BODs has insignificant and negative impact on the firm performance. On the other hand percentage of directors having post-graduation degree has positive and notable impact on the performance of the firm.
\end{abstract}

Keywords: Composition of Board of Directors, Bombay Stock Exchange, Return on Equity, Firm Performance.

\section{Introduction}

A number of research papers in management literature have presumed that managers with higher education have better cognitive abilities, training or social influence which improves firm performance. The BODs play a significant role in a company's decision-making process and key operations of a firm which are pivotal to the mission and vision of the firm. The BODs have the responsibility of the whole organisation. They must possess remarkable skills, knowledge and experience.

Radlach et. al. (2008) studied the impact of the percentage of women, average age of all board members, percentage of minority directors, size of the board and the percentage of independent directors in the board composition on the performance of financial institutions and identified that the composition of the board of directors affects the performance of financial institutions.

Educational background of BODs may determine the level of knowledge that he/she has. Although education in Business Management is not a necessary requirement for entering a business world but the members of the BODs must have the knowledge of business and economy. The BODs having good knowledge of business and economy are more capable to manage the business and to take important decisions.

In this present study, we are trying to address the question whether educational background of board of directors and composition of board of directors will result in improvement of performance of the firm or not. This research comprises of five sections. Section 1 gives an introduction about the topic of study. Section 2 is the brief review of literature. Section 3 provides objective of the study, database and methods applied for data analysis. Section 4 is the analysis of data and section 5 is the summary of findings and conclusions.

\section{Review of Literature}

There has been detailed study on the areas such characteristics of BODs and firm performance, education of BODs, independence of BODs and corporate 
governance, characteristics and education of chief operating officer and firm's performance. A short review of literature has been done with respect to effect of board of director's educational background, composition of board and various other characteristics of the board on firm's performance. Abidin et al. (2009) indicated that size and composition of BODs have direct and significant impact on the performance of the firms listed in Stock Exchange of Malaysia on the basis of randomly selected sample of 75 listed companies. Certo (2003) identified the need of good level of education for gaining manager's reputation and taking business decisions. Many studies were conducted to find significance of education of BODs on firm performance. Rajagopalan and Datta (1996) in their study on the relationships between the characteristics of CEO and industry conditions indicated a direct alignment of the CEO educational level with the company's performance.

Frydman, Carola, 2006 mentioned in their study that CEOs with strong technical educational background and $\mathrm{R} \& \mathrm{D}$ experience are more focussed on innovation resulting in improved firm performance. However, they observed firms with low profitability cuts their spending in R\&D. Darmadi (2013) examined the impact of education of the BODs on the performance of 392 Indonesian firms from 2005 to 2010. The study concluded that the performance of those firms with CEOs holding degrees from prestigious domestic universities is significantly better than those firms having CEOs without such degrees.

Daellenbach et al. (1999) investigated that the educational background of the CEO and the top management teams can be used for assessing the better understanding of a firm's vision and strategic direction. Daellenbach et al. (1999) concluded that firms for gaining the competitive advantage of innovative products should select top management having operations and technical expertise. Kokeno and Muturi (2016) in their study on the impact of CEO characteristics on firm performance of firms listed in the Nairobi Securities Exchange identified the significant effect of CEO education on firm performance. However some of the studies failed to identify any relationship between the educational background of BODs and the performance of firm. Like, Gottesman and Morey (2010) in their study on the US firms found no significant relationship between education of CEO education and performance of firm. Lindorff and Jonson (2013) investigated the influence of CEO holding MBA degree on the dividend and changes in price of share and concluded that CEO education do not have significant influence on firm performance.

Bathula (2008) conducted a study on BODs of 156 firms listed on New Zealand Stock Exchange from 2004 to 2007 and concluded that the presence of $\mathrm{PhD}$ qualified members on board is negatively associated with firm's performance and they do not add any value to firm's performance. Jalbert et al.
(2002) in their study on the forbes 800 firms identified the positive relation between the reputation of the CEO's graduate school and Return on Assets. They found that performance of the CEOs having graduate degree from prestigious institute significantly better based on Tobin's $Q$ and significantly worse in terms of Return on Assets.

Bhagat et al. (2010) in their study on the educational background of 1800 CEOs of S \& P's 1500 companies did not found any affirmation of linkage of education of BODs with CEO turnover and firm performance. Mahadeo et al. (2012) also identified negative relationship between the diversity of education of BODs and the performance of firms listed on Mauritius Stock Exchange.

\section{Objectives, Database and Methods Objectives}

This study is focused on to explore the association (relationship) among Return on Equity (ROE) and Return on Capital Employed (ROCE) as dependent variable and three independent variables i.e. size of board, proportion of board have post graduate degree/ qualification and proportion of independent directors in the board of directors.

\section{Database \\ The present work is depending on the data collected (secondary) from annual report, financial statements of the seven companies of Indian service sector listed on the Bombay Stock Exchange in India. These seven companies' area of operation comprises of telecommunication, consultancy and software development. Time series data from 2014-15 to 2018-19 has been analyzed for dependent and independent variables. Appendex-1 indicated the size of board, proportion of directors having post graduate degree and proportion of independent director in the board from 2014-15 to 2018-19 for seven companies. Appendex-2 shows return on equity and return on capital employed from 2014-15 to 2018-19 for seven companies.}

\section{Methods}

In order to explore the relationship among firm performance indicator i.e. Return on Equity and Return on Capital Employed as dependent variable and three independent variables, following equation has been used:

\footnotetext{
$Y=\beta_{0}+\beta_{1} X_{1}+\beta_{2} X_{2}+\beta_{3} X_{3}+\mu$

Where:

$\beta_{0}=$ Natural $\log$ of intercept $\mathrm{A}$

$Y=$ Return on Equity/ Return on Capital Employed

$X_{1}=$ Size of Board of Directors

$X_{2}=$ Proportion of directors with post graduation degree

$X_{3}=$ Proportion of independent directors in board

$\beta_{1}, \beta_{2}, \beta_{3}=$ Output elasticises (Coefficients)

$\mu=$ Error term

For analysis of data two methods have been employed. First,
} 
Matrix Correlation Analysis to measure the degree of variables moves in relation to each other. Second is the Linear Regression Analysis to understand and quantify association (relationship) between dependent and independent variables.

\section{Data Analysis}

This study analyzed the impact of size of board, proportion of directors with post graduation degree or qualification equivalent to post graduation and proportion of independent directors in the board on the performance of the companies of Indian service sector. Table 1 shows descriptive statistics. The mean for size of board is approx 11 directors with minimum 8 directors and maximum 16 directors. The means for proportion of directors with post graduation degree is $75.34 \%$ with minimum $54.55 \%$ and maximum $100 \%$. The average of proportion of independent directors in the board is $56.50 \%$ with minimum $30.77 \%$ and maximum $87.5 \%$. The average for return on equity is $24.89 \%$ with minimum $0.58 \%$ and maximum $45.50 \%$. The mean for return on capital employed is $29.37 \%$ with minimum $4.64 \%$ and maximum $53.73 \%$.

Table-1 Descriptive Statistics

\begin{tabular}{|c|c|c|c|c|c|}
\hline & & & $\begin{array}{l}\text { In the } \\
\text { Boar } \\
\text { d } \\
\end{array}$ & & \\
\hline Size of Board & 1 & & & & \\
\hline $\begin{array}{l}\text { Proportion of } \\
\text { directors } \\
\text { have PG } \\
\text { Degree }\end{array}$ & $\begin{array}{c}0.0 \\
22 \\
*\end{array}$ & 1 & & & \\
\hline $\begin{array}{l}\text { Proportion of } \\
\text { Independent } \\
\text { in the Board }\end{array}$ & $\begin{array}{c}- \\
0.4 \\
39 \\
\end{array}$ & $\begin{array}{c}0.022 \\
* \\
\end{array}$ & 1 & & \\
\hline $\mathrm{ROE}$ & $\begin{array}{c}- \\
0.0 \\
12 \\
\end{array}$ & $\begin{array}{c}0.525 \\
* \\
\end{array}$ & $\begin{array}{c}- \\
0.156 \\
\end{array}$ & 1 & \\
\hline ROCE & $\begin{array}{c}0.0 \\
17\end{array}$ & $\begin{array}{c}0.460 \\
*\end{array}$ & $\begin{array}{c}- \\
0.122\end{array}$ & $\begin{array}{c}0 . \\
98 \\
3 *\end{array}$ & 1 \\
\hline
\end{tabular}

Note: **. Correlation is significant at the 0.10 level Computed by author

Based upon the significant correlation found between ROE and 'Proportion of directors having PG Degree', regression analysis was conducted to find the way these two variables are related. Before testing the regression analysis, normality test was performed to confirm these variable belong to the

Descriptive Statisticformal distribution. Results are shown in Table 3.

\begin{tabular}{lr|r|r|r} 
& N & \multicolumn{1}{l|}{ Minimum } & Maxin \\
\hline Size of Board & 35 & 8 & \\
\hline PG Degree & 35 & 5 & \\
\hline Ratio of PG & 35 & 54.55 & \\
\hline Independent Director & 35 & 4 & \\
\hline Ratio Independent & 35 & 30.77 & \\
\hline ROE & 35 & .58 & \\
\hline ROCE & 35 & 4.64 & \\
\hline Valid N (listwise) & 35 & & \\
\hline
\end{tabular}

Computed by author

\section{Correlation Matrix}

The correlation matrix among variables has been shown in Table 2. The results shows, that size of board has negative and insignificant correlation with return on equity and positive correlation with return on capital employed. Proportion of directors having post graduation degree has positive and significant correlation with return on equity $(\alpha=0.525$, significant at $10 \%$ level of significance) and return on capital employed ( $\alpha=0.460$ at $10 \%$ level of significance). Proportion of independent directors in the board has negative and insignificant correlation with return on equity and return on capital employed.

Table2. Descriptive Statistics

\begin{tabular}{|l|c|c|c|l|l|}
\hline & & $\begin{array}{c}\text { Propor } \\
\text { tion of } \\
\text { direct } \\
\text { ors }\end{array}$ & $\begin{array}{c}\text { Propo } \\
\text { rtion } \\
\text { of }\end{array}$ & & \\
& Siz & e & & \\
having & PG & Indep & R & O \\
Variables & Bo & Degre & enden & O & C \\
ard & $\mathrm{e}$ & $\mathrm{t}$ & $\mathrm{E}$ & $\mathrm{E}$ \\
\hline
\end{tabular}
Maximum
\begin{tabular}{ll} 
Mean & Std. Deviation \\
\hline
\end{tabular}

\begin{tabular}{|c|c|c|c|c|c|c|}
\hline & \multicolumn{6}{|c|}{ Table 3. Tests of Normality } \\
\hline & $\begin{array}{r}\text { Kolm } \\
\text { Sm }\end{array}$ & $\begin{array}{l}\text { gol } \\
\text { rno }\end{array}$ & & Shapir & $0-4$ & \\
\hline & $\begin{array}{l}\text { Statisti } \\
\text { c }\end{array}$ & df & Sig. & $\begin{array}{l}\text { Statisti } \\
\text { c }\end{array}$ & df & Sig. \\
\hline $\begin{array}{l}\text { Proportio } \\
\mathrm{n} \text { of } \\
\text { directors } \\
\text { having } \\
\mathrm{PG} \\
\text { Degree }\end{array}$ & .140 & $\begin{array}{l}3 \\
5\end{array}$ & .078 & .943 & $\begin{array}{l}3 \\
5\end{array}$ & $\begin{array}{r}.07 \\
0\end{array}$ \\
\hline ROE & .068 & $\begin{array}{l}3 \\
5\end{array}$ & $.200_{*}$ & .977 & $\begin{array}{l}3 \\
5\end{array}$ & $\begin{array}{r}.67 \\
0\end{array}$ \\
\hline ROCE & .127 & $\begin{array}{l}3 \\
5\end{array}$ & .171 & .950 & $\begin{array}{l}3 \\
5\end{array}$ & $\begin{array}{r}10 \\
9\end{array}$ \\
\hline
\end{tabular}

*. This is a lower bound of the true significance.

a. Lilliefors Significance Correction

Table 3 shows that Shapiro Wilk statistics result is insignificant $(p>0.5)$ which means that there is not significant reason to reject the null hypothesis of normality. Hence all the three variables are normally distributed. This normality test meets the criteria of fitting univariate linear regression model in the data between the

dependent variable ROE and independent variable 'Proportion of directors having PG Degree'.

\section{Linear Regression Analysis}

Table 4 shows the result of regression analysis for return on equity as dependent variable and 'Proportion of directors having PG Degree' as independent 
variables. The value for R-square is 0.20911868 which suggests that approximately $20 \%$ change in return on equity (ROE) can be attributed to the independent variables taken into study. Further results shows, that impact of size of 'Proportion of directors having PG Degree' have significant influencing factor on ROE $(p<0.00)$. The coefficient 2.63686096 of 'Proportion of directors having PG Degree' variable explains that $1 \%$ change in this variable will result in approx $2.63 \%$ change in ROE.

\section{Table-4 Regression Analysis (ROE as dependent variable)}

\begin{tabular}{|c|c|}
\hline Multiple R & 0.457294959 \\
\hline R Square & 0.20911868 \\
\hline Adjusted R Square & 0.132581778 \\
\hline Observations & 35 \\
\hline
\end{tabular}

\begin{tabular}{|l|r|r|r|r|}
\hline & $\begin{array}{c}\text { Coeff } \\
\text { icient } \\
s\end{array}$ & $\begin{array}{c}\text { Stand } \\
\text { ard } \\
\text { Error }\end{array}$ & t Stat & $\begin{array}{c}P- \\
\text { valu } \\
e\end{array}$ \\
\hline Intercept & - & & & \\
& 4.560 & & - & \\
& 1934 & 6.115 & 0.745 & 0.46 \\
& 23 & 113 & 73 & 1451 \\
\hline Proportion of & 2.636 & & & \\
directors with & 8609 & 0.953 & 2.764 & 0.00 \\
PG degree (\%) & 6 & 89 & 323 & 9516 \\
\hline
\end{tabular}

Table 5 shows the result of regression analysis for return on capital employed (ROCE) as dependent variable and the variable 'Proportion of directors having PG Degree'. The value for R-square is 0.143318513 which is low and indicates that around $14 \%$ change in return on capital employed will results from the independent variables. Proportion of directors with post graduation degree or equivalent to PG degree has coefficient 1.492551778 which means $1 \%$ change in proportion of directors with PG degree will result in around $1.49 \%$ change in return on capital employed. Independent variable 'Proportion of directors with PG degree' has significant impact on the dependent variable ROCE $(\mathrm{p}<.05)$.

\section{Table-5 Regression Analysis (ROCE as dependent variable)}

\begin{tabular}{|c|c|}
\hline Multiple R & 0.378574316 \\
\hline R Square & 0.143318513 \\
\hline Adjusted R Square & 0.060413853 \\
\hline Observations & 35 \\
\hline
\end{tabular}

\begin{tabular}{|l|l|l|l|l|}
\hline & $\begin{array}{c}\text { Coeff } \\
\text { icient } \\
s\end{array}$ & $\begin{array}{c}\text { Stand } \\
\text { ard } \\
\text { Error }\end{array}$ & Stat & $\begin{array}{c}P \text { - } \\
\text { valu } \\
e\end{array}$ \\
\hline Intercept & $\begin{array}{l}1.122 \\
4165\end{array}$ & 4.744 & 0.236 & 0.81 \\
& 76 & 783 & 558 & 4556 \\
\hline Proportion of & 1.492 & & & \\
directors with & 5517 & 0.740 & 2.016 & 0.04 \\
PG degree (\%) & 78 & 134 & 597 & 2471 \\
\hline
\end{tabular}

\section{Conclusion}

Service sector is one of the prominent sectors of Indian economy. Service sector contributes around $50 \%$ of India's GDP for last decade. Management \& employees' educational acumen and customer satisfaction are considered as driving forces for service sector. From the above analysis it is found that size of board and independence of boards has insignificant impact on the performance of companies operating in India's service sector. Although directors having post graduate or equivalent qualification has significant impact on the service sector companies' performance but probability of occurring is low. Hence it can be concluded that size of board, and independence of board has insignificant impact on the performance of the service sector companies in India while directors with post graduation qualification have somewhat significant impact on the performance of the companies.

\section{References:}

1. Abidin, Z. Z., Kamal, N. M., \& Jusoff, K. (2009). Board structure and corporate performance in Malaysia. International Journal of Economics and Finance, 1(1), 150-164.

2. Bathula, H. (2008). Board characteristics and firm performance: Evidence from New Zealand. PhD Thesis. Auckland University of Technology.

3. Bhagat, S., Bolton, B., and Subramanian, A. (2010), "CEO education, CEO turnover, and firm performance", working paper, University of Colorado at Boulder, 3 August.

4. Certo, S. T. (2003). Influencing initial public offering investors with prestige: signaling with board structures. The Academy of Management Journal, 28(3), 432-446.

5. Daellenbach, U. S., \& McCarthy, A. M. (1999). Commitment to innovation: The impact of top management team characteristics. R $\{\&\} \mathrm{D}$ Management, 29(3), 199.

6. Darmadi, S. (2013). Board members' education and firm performance: evidence from a developing economy. International Journal of Commerce and Management, 23(2), 113-135 
7. Frydman, C, 2006, Rising through the ranks: The evolution of the market for corporate executives, 1936-2003, working paper, MIT.

8. Gottesman, A. A. and Morey, M. R. (2006a), "Does a better education make for better managers? An empirical examination of CEO educational quality and firm performance", working paper, Pace University, New York, 21 April.

9. Jalbert, T., Rao, R., and Jalbert, M. (2002), "Does school matter? An empirical analysis of CEO education, compensation, and firm performance", International Business and Economics Research Journal, Vol. 1 No. 1, pp. 83-98.

10. Jayaraman, N.; Khorana, A.; Nelling, E.; and Covin, J.. "CEO Founder Status and Firm Financial Performance." Strategic Management Journal, 21 (2000), 12151224.

11. Kokeno, S. O., \& Muturi, W. (2016). Effect of chief executive officer's charactristics on the financial performance of firms listed at the Nairobi Securities Exchange. International Journal of Economics, Commerce and Management, IV, 7, 307318.

12. Kokeno, S. O., \& Muturi, W. (2016). Effect of chief executive officer's characteristics on the financial performance of firms listed at the Nairobi Securities Exchange.
International Journal of Economics, Commerce and Management, IV, 7, 307318.

13. Lindorff, M., \& Jonson, E. P. (2013). CEO business education and firm financial performance: a case for humility rather than hubris. Education + Training, 55(4/5), 461-477.

14. Mahadeo, J. D., Soobaroyen, T., \& Hanuman, V. O. (2012). Board composition and financial performance: Uncovering the effects of diversity in an emerging economy. Journal of Business Ethics, 105(3), 375-388.

15. Radlach, P., Schlemmbach, K., \& Smith, E. (2008). The board of directors and its influence on risk propensity and firm performance: An empirical study of their relations in the banking sector (Master Dissertation). Kristianstad University College.

16. Rajagopalan, N., \& Datta, D. K. (1996). CEO characteristics: does industry matter? The Academy of Management Journal, 39(1), 197-215.

Appendex-1- Size of Board, Proportion of Directors with PG Degree and Proportion of Independent Director in Board

\begin{tabular}{|c|c|c|c|c|c|c|}
\hline Year & Company's Name & $\begin{array}{c}\text { Size } \\
\text { of } \\
\text { Boar } \\
\text { d }\end{array}$ & $\begin{array}{c}\text { No. of } \\
\text { Directors } \\
\text { With } \\
\text { Post } \\
\text { Graduate } \\
\text { Degree } \\
\end{array}$ & $\begin{array}{c}\text { Proportion of } \\
\text { Directors } \\
\text { have PG } \\
\text { Degree } \\
\end{array}$ & $\begin{array}{c}\text { No. of } \\
\text { Independen } \\
t \\
\end{array}$ & $\begin{array}{l}\text { Proportion } \\
\text { of }\end{array}$ \\
\hline 2015 & \multirow{5}{*}{ Bharti Airtel Limited } & 16 & 11 & 68.75 & 9 & 56.25 \\
\hline 2016 & & 14 & 10 & 71.43 & 7 & 50 \\
\hline 2017 & & 12 & 7 & 58.33 & 6 & 50 \\
\hline 2018 & & 13 & 8 & 61.54 & 7 & 53.85 \\
\hline 2019 & & 11 & 6 & 54.55 & 5 & 45.45 \\
\hline 2015 & \multirow{5}{*}{$\begin{array}{l}\text { HCL Technologies } \\
\text { Limited }\end{array}$} & 9 & 5 & 55.56 & 6 & 66.67 \\
\hline 2016 & & 10 & 7 & 70.00 & 7 & 70.00 \\
\hline 2017 & & 12 & 9 & 75.00 & 6 & 50.00 \\
\hline 2018 & & 11 & 8 & 72.73 & 8 & 72.73 \\
\hline 2019 & & 11 & 8 & 72.73 & 8 & 72.73 \\
\hline 2015 & \multirow{5}{*}{$\begin{array}{l}\text { Larsen \& Toubro } \\
\text { Infotech } \\
\text { Limited }\end{array}$} & 13 & 10 & 76.92 & 4 & 30.77 \\
\hline 2016 & & 12 & 9 & 75.00 & 4 & 33.33 \\
\hline 2017 & & 12 & 9 & 75.00 & 7 & 58.33 \\
\hline 2018 & & 13 & 10 & 76.92 & 6 & 46.15 \\
\hline 2019 & & 12 & 9 & 75.00 & 6 & 50.00 \\
\hline
\end{tabular}




\begin{tabular}{|c|c|c|c|c|c|c|}
\hline 2015 & \multirow{5}{*}{$\begin{array}{l}\text { Tata Consultancy } \\
\text { Services } \\
\text { Limited }\end{array}$} & 12 & 10 & 83.33 & 6 & 50.00 \\
\hline 2016 & & 11 & 9 & 81.82 & 6 & 54.55 \\
\hline 2017 & & 13 & 11 & 84.62 & 6 & 46.15 \\
\hline 2018 & & 12 & 11 & 91.67 & 7 & 58.33 \\
\hline 2019 & & 13 & 9 & 69.23 & 9 & 69.23 \\
\hline 2015 & \multirow{5}{*}{$\begin{array}{l}\text { Tech Mahindra } \\
\text { Limited }\end{array}$} & 10 & 7 & 70.00 & 5 & 50.00 \\
\hline 2016 & & 11 & 7 & 63.64 & 5 & 45.45 \\
\hline 2017 & & 10 & 7 & 70.00 & 5 & 50.00 \\
\hline 2018 & & 10 & 7 & 70.00 & 5 & 50.00 \\
\hline 2019 & & 10 & 7 & 70.00 & 5 & 50.00 \\
\hline 2015 & \multirow{5}{*}{ Wipro Limited } & 11 & 7 & 63.64 & 6 & 54.55 \\
\hline 2016 & & 8 & 6 & 75.00 & 7 & 87.50 \\
\hline 2017 & & 9 & 7 & 77.78 & 7 & 77.78 \\
\hline 2018 & & 10 & 7 & 70.00 & 7 & 70.00 \\
\hline 2019 & & 11 & 9 & 81.82 & 8 & 72.73 \\
\hline 2015 & \multirow{5}{*}{$\begin{array}{l}\text { Zensar Technologies } \\
\text { Limited }\end{array}$} & 10 & 10 & 100.00 & 6 & 60.00 \\
\hline 2016 & & 12 & 12 & 100.00 & 6 & 50.00 \\
\hline 2017 & & 10 & 10 & 100.00 & 5 & 50.00 \\
\hline 2018 & & 12 & 11 & 91.67 & 8 & 66.67 \\
\hline 2019 & & 12 & 10 & 83.33 & 7 & 58.33 \\
\hline
\end{tabular}

Appendex-2- Details of Return on Equity \& Return on Capital Employed

\begin{tabular}{|c|c|c|c|}
\hline Year & Company's Name & ROE & ROCE \\
\hline 2015 & \multirow{5}{*}{ Bharti Airtel Limited } & 8.52 & 8.05 \\
\hline 2016 & & 9.44 & 8.32 \\
\hline 2017 & & 5.66 & 6.45 \\
\hline 2018 & & 1.6 & 4.64 \\
\hline 2019 & & 0.58 & 5.06 \\
\hline 2015 & \multirow{5}{*}{ HCL Technologies Limited } & 36.1 & 42.01 \\
\hline 2016 & & 30.77 & 36.98 \\
\hline 2017 & & 28.96 & 34.31 \\
\hline 2018 & & 27.5 & 33.5 \\
\hline 2019 & & 28.22 & 33.58 \\
\hline 2015 & \multirow{5}{*}{ Larsen \& Toubro Infotech Limited } & 45.5 & 49.26 \\
\hline 2016 & & 44.03 & 49.42 \\
\hline 2017 & & 37.95 & 47.05 \\
\hline 2018 & & 34.65 & 43.77 \\
\hline 2019 & & 34.99 & 46.14 \\
\hline 2015 & \multirow{5}{*}{ Tata Consultancy Services Limited } & 43.05 & 53.73 \\
\hline 2016 & & 41.81 & 52.25 \\
\hline 2017 & & 33.21 & 41.71 \\
\hline 2018 & & 32.92 & 41.19 \\
\hline 2019 & & 38.91 & 52.14 \\
\hline 2015 & \multirow{3}{*}{ Tech Mahindra Limited } & 22.74 & 25.19 \\
\hline 2016 & & 24.18 & 26.42 \\
\hline 2017 & & 19.12 & 21.87 \\
\hline
\end{tabular}




\begin{tabular}{|c|c|c|c|}
\hline 2018 & & 21.93 & 24.25 \\
\hline 2019 & & 21.8 & 24.65 \\
\hline 2015 & \multirow{5}{*}{ Wipro Limited } & 25.61 & 29 \\
\hline 2016 & & 21.62 & 24.67 \\
\hline 2017 & & 18.56 & 21.52 \\
\hline 2018 & & 17.36 & 20.1 \\
\hline 2019 & & 16.61 & 19.75 \\
\hline 2015 & \multirow{5}{*}{ Zensar Technologies Limited } & 23.76 & 23.35 \\
\hline 2016 & & 24.82 & 24.47 \\
\hline 2017 & & 15.97 & 15.74 \\
\hline 2018 & & 15.37 & 14.63 \\
\hline 2019 & & 17.54 & 22.98 \\
\hline
\end{tabular}

